\title{
PERANCANGAN DAN PEMBUATAN WEB DENGAN BLOGSPOT
}

\author{
Alfie Hidayat (20620018) \\ Vionna Laviolita Achintiya (20620011)
}

Mahasiswa Program Studi Teknik Komputer, Jurusan Teknologi Informasi, Politeknik Negeri

Samarinda

Email: alfiehidayat121@gmail.com

vionnalaviolita11@gmail.com

\begin{abstract}
Abstrak
Seiring dengan berjalannya perkembangan zaman, ilmu pengetahuan dan teknologi informasi serta komunikasi semakin canggih. Kita tidak akan mengalami kesulitan lagi untuk mendapatkan pengetahuan dan informasi, karena sekarang segala sesuatu sudah dapat dicari melalui media internet, yang sebelumnya media berita diberitakan dalam media koran, radio, dan lainnya,sekarang berita dapat lebih mudah kita dapatkan melalui handphone atau telpon genggam yang bias kita gunakan dalam sehari-hari sekarang karena zaman makin berkembang dan teknologi makin canggih kita bisa lebih mudah mendapatkan berita terbaru dengan mencarinya di google. Melihat salah satu website terkenal dari google yaitu Blog atau Weblog.
\end{abstract}

Kata Kunci : Teknologi Informasi, Internet, Blog

\section{Pendahuluan}

Perkembangan ilmu pengetahuan dan teknologi telah begitu pesat pada jaman ini. Perkembangan ilmu yang terjadi selama ini tidaklah berlangsung secara tiba-tiba, melainkan terjadi secara bertahap. Perkembangan ilmu terjadi karena manusia selalu dihadapkan pada tantangan alam, situasi dan kondisi yang memacu daya kreativitasnya. Selalu terdapat dorongan untuk membuat manusia melangkah ke arah kemajuan dan dorongan tersebut adalah rasa ingin tahu (curiousity) (Mutansyir, 2002: 63). Semua hal yang terjadi sampai sekarang ini merupakan rangkaian panjang sejarah peradaban manusia.[1]

Website adalah kumpulan halaman dalam suatu domain yang memuat tentang berbagai informasi agar dapat dibaca dan dilihat oleh pengguna internet melalui sebuah mesin pencari. Biasanya untuk tampilan awal sebuah website dapat diakses melalui halaman utama menggunakan browser dengan menuliskan URL yang tepat. Website dibuat dengan berbagai macam alasan. Namun, alasan yang paling utama dan menjadi alasan website dibuat untuk pertama kalinya dalam sejarah adalah untuk saling bertukar informasi. Manfaat website di zaman sekarang juga sudah meluas, bukan hanya sekadar wadah bertukar informasi. Media sosial telah membuat perombakan besar tentang definisi interaksi sosial. Media sosial juga berfungsi sebagai personal 
branding. LinkedIn adalah salah satu contoh media sosial yang bergerak di bidang ini. Contohnya adalah media YouTube yang kini sedang menjamur di Indonesia. Untuk pengusaha dan pebisnis, website sangat bermanfaat sebagai media untuk mempromosikan produknya. Dengan adanya website, informasi mengenai produk barang atau jasa miliknya dapat disebarluaskan dengan mudah tanpa biaya yang tinggi.[2]

Membuat website adalah salah satu hal yang dirasa sulit untuk sebagian orang. Khususnya para pemula yang belum pernah sekalipun berkenalan dengan dunia komputer, internet apalagi website. Para pemula cenderung berpikir bahwa membuat website adalah sesuatu yang rumit, membuat pusing dan hanya orang-orang tertentu yang bisa. Berbeda dengan sekarang, membuat website seakan mudah dalam genggaman.

\section{Metode/Perancangan/}

\section{Pengertian blog.}

Blog adalah jenis situs web yang isinya memuat gagasan dari satu atau beberapa penulis dan memiliki urutan penerbitan secara kronologis (dari konten terbaru hingga konten terlama). Saat ini blog memiliki tampilan dan susunan yang sangat beragam sesuai dengan fungsi dari blog itu sendiri. Dari blog dengan banyak sidebar hingga blog dengan hanya satu kolom. Pada dasarnya sebuah blog memiliki struktur standar, berikut beberapa struktur standar pada blog:

1. Header : Header terletak pada bagian atas blog yang biasanya berisi judul blog, deskripsi blog dan menu dari blog itu sendiri.

2. Navbar: Navbar terletak pada bagian atas judul. Navbar sendiri mempunyai fungsi yaitu untuk memudahkan kita(pemilik blog/editor) dalam mengelola blog.

3. Main blog: Main blog terletak di tengah-tengah blog. Disinilah lokasi posting dari blog. Main blog juga mempunyai beberapa struktur diantaranya judul, tanggal, nama penulis dan kolom komentar.

4. Sidebar: Sidebar biasanya berisi posting populer dan arsip. Kita dapat menambahkan widget lain, seperti kalender, jam, dan banyak lainnya. Itu dapat terletak di sisi kiri atau kanan blog.

5. Footer: Footer terletak di bagian bawah blog. Informasi singkat dari pemilik blog biasanya diisi pada alamat email, kontak atau formulir berlangganan.[3]

2. Sejarah blog.

Blog pertama mungkin adalah halaman "What's New" di browser Mosaic yang dibuat oleh Marc Andersen (1993). Mosaic adalah browser pertama sebelum Internet Explorer dan bahkan Nestscape. Hingga (1998), jumlah blog yang ada masih sangat sedikit. Hal ini karena membuat blog pada saat itu membutuhkan keterampilan dan pengetahuan khusus tentang pembuatan website, HTML, dan Web Hosting, sehingga hanya mereka yang berpartisipasi di Internet, administrator sistem atau desainer web yang kemudian membuat blog mereka di waktu luang mereka. Blognya sendiri. Blog ini dipopulerkan oleh Blogger.com, yang dimiliki oleh Pyra Lab dan kemudian diakuisisi oleh Google (2002). Sejak itu, ada banyak aplikasi untuk perkembangan para penulis blog.[4] 
3. Fungsi blog.

Blog mempunyai beberapa fungsi, diantaranya yaitu :

1. Mengasah kemampuan penulis.

2. Media publikasi untuk siapa saja yang membutuhkan.

3. Bukti profesionalitas.

4. Sarana untuk branding.

5. Menghasilkan uang, bisa menggunakan ads google misalnya.

\section{Manfaat blog.}

Blog mempunyai berbagai macam manfaat, salah satunya adalah untuk sarana berbagi ilmu mealui internet. Misalkan seperti yang akan kami buat setelah ini, kami ingin membuat blog dengan judul "ILMU KOMPUTER DAN JARINGAN". Ya, disini kami ingin berbagi ilmu tentang komputer dan jaringan, seperti pengertian tentang apa itu arduino, cara konfigurasi, dan banyak lainnya. Selain untuk sarana berbagi ilmu, kita juga dapat memanfaatkan blog untuk tempat jual beli, dapat berupa barang ataupun hewan dan tumbuhan.[5]

\section{Cara membuat.}

Berikut cara membuat blog menggunakan blogger.com :

\section{Pertama-tama kita buka halaman blogger.com.}

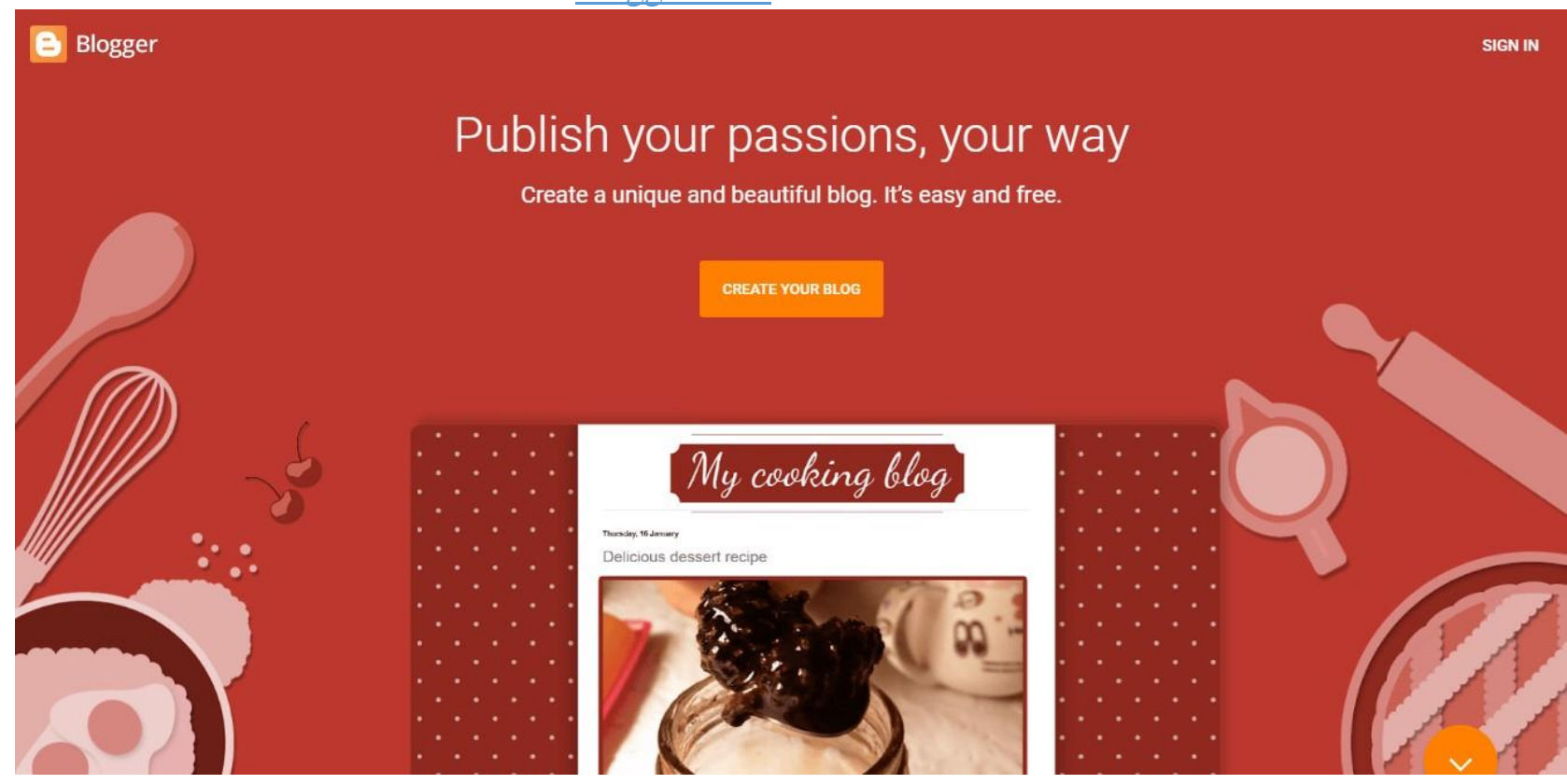


2. Lalu, klik pada bagian "CREATE YOUR BLOG".

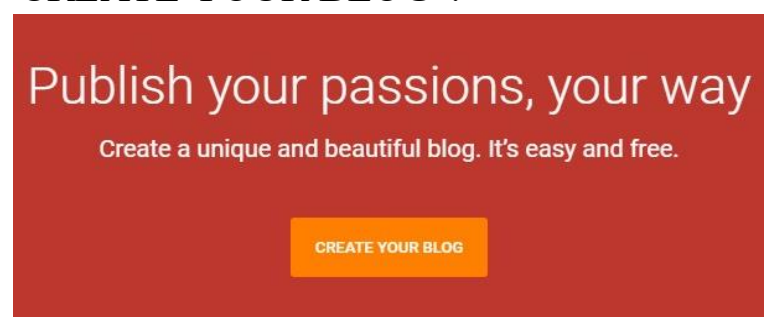

3. Selanjutnya masukkan email kita.

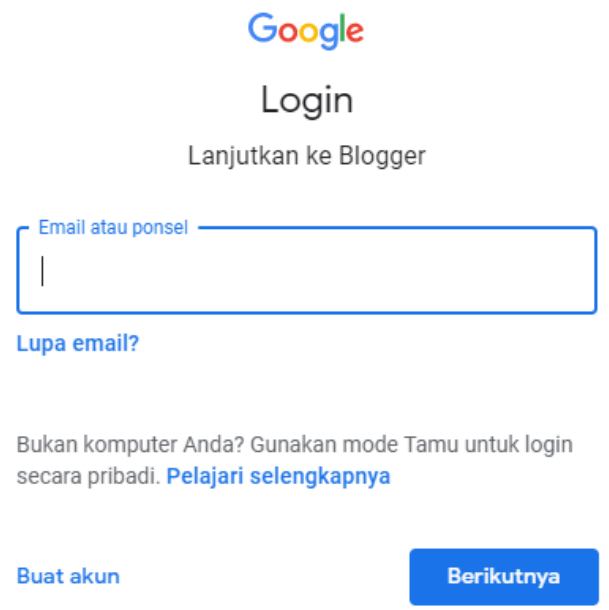

4. Kemudian masukkan password dari email kita.

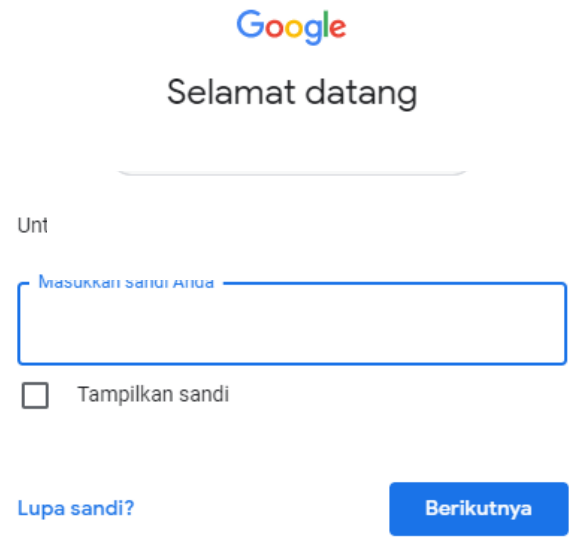


5. Pilih nama untuk blog kita, ini merupakan judul yang akan ditampilkan di bagian atas Blog kita.

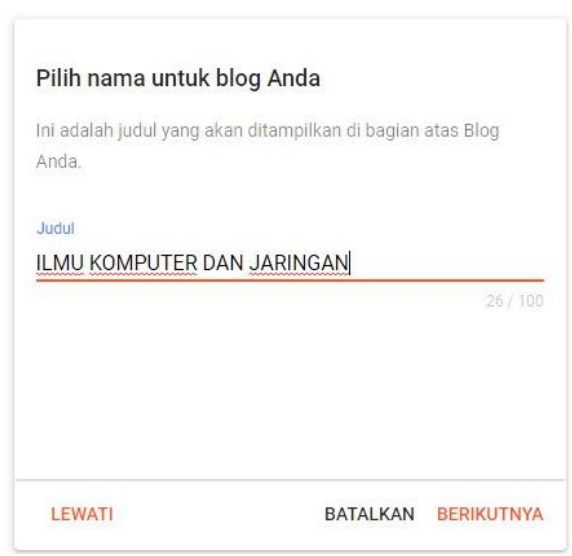

6. Pilih domain/URL untuk blog kita, di project kami, kami menggunakan vionnalfie.blogspot.com.

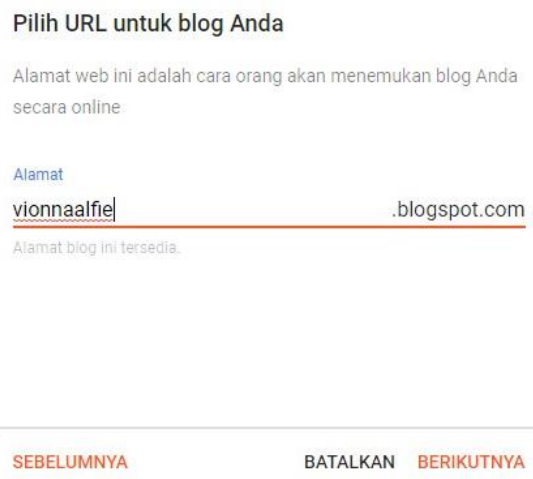

7. Konfirmasi nama tampilan, disini kami menggunakan VionnaAlfie.

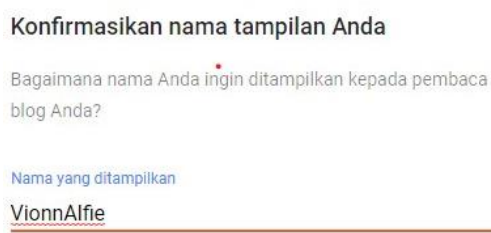


8. Jika sudah melakukan konfirmasi tampilan, maka akan lanjut ke halaman seperti di bawah ini.

$$
\equiv \Theta
$$

Q Telusuri postingan

ILMU KOMPUTER DAN
JARINNGAN
+ POSTINGAN BARU
目 Postingan
iii Statistik
$\square$ Komentar
\$ Penghasilan
$\square$ Halaman
国 Tata Letak
? Tema
† Setelan

'Notifikasi (1)

Widget Ikuti Lewat Email (Feed Burner) akan dinonaktifkan

Anda menerima informasi ini karena blog Anda menggunakan widget Ikuti Lewat Email (FeedBurner).

Baru-baru ini, tim FeedBurner merilis pengumuman update sistem, yang menyatakan layanan langganan email akan dihentikan pada Juli 2021

Setelah Juli 2021, feed akan tetap berfungsi, tetapi email otomatis ke pelanggan Anda tidak akan didukung lagi. Jika ingin terus mengirim email, download

kontak pelanggan Anda. Pelajari caranya

Semua (0)

Tidak ada entri.

9. Tentukan tema yang ingin kita gunakan, dengan cara mengklik pada bagian Tema.

\section{戸 Tema}

10. Selanjutnya akan masuk ke halaman pemilihan tema, terdapat banyak pilihan tema seperti dibawah ini

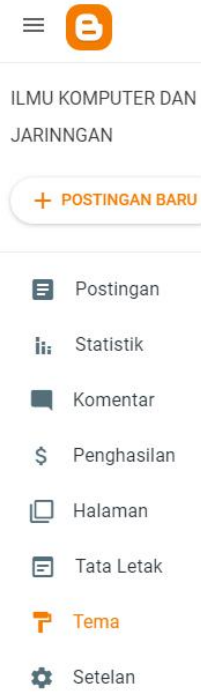

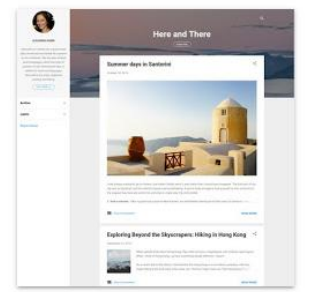

Tema Saya

Contempo Light

Contempo
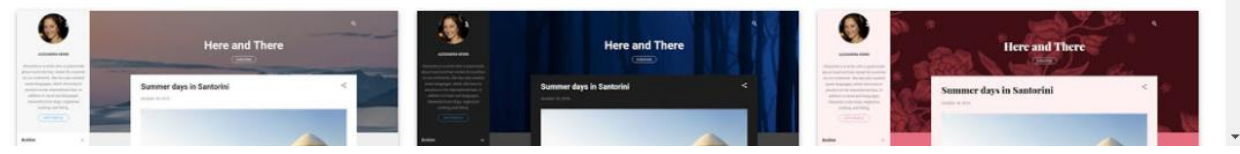
11. Di sini saya memilih tema Contempo Flamingo, jika sudah sesuai dengan keinginan kita selanjutnya klik pada bagian terapkan.
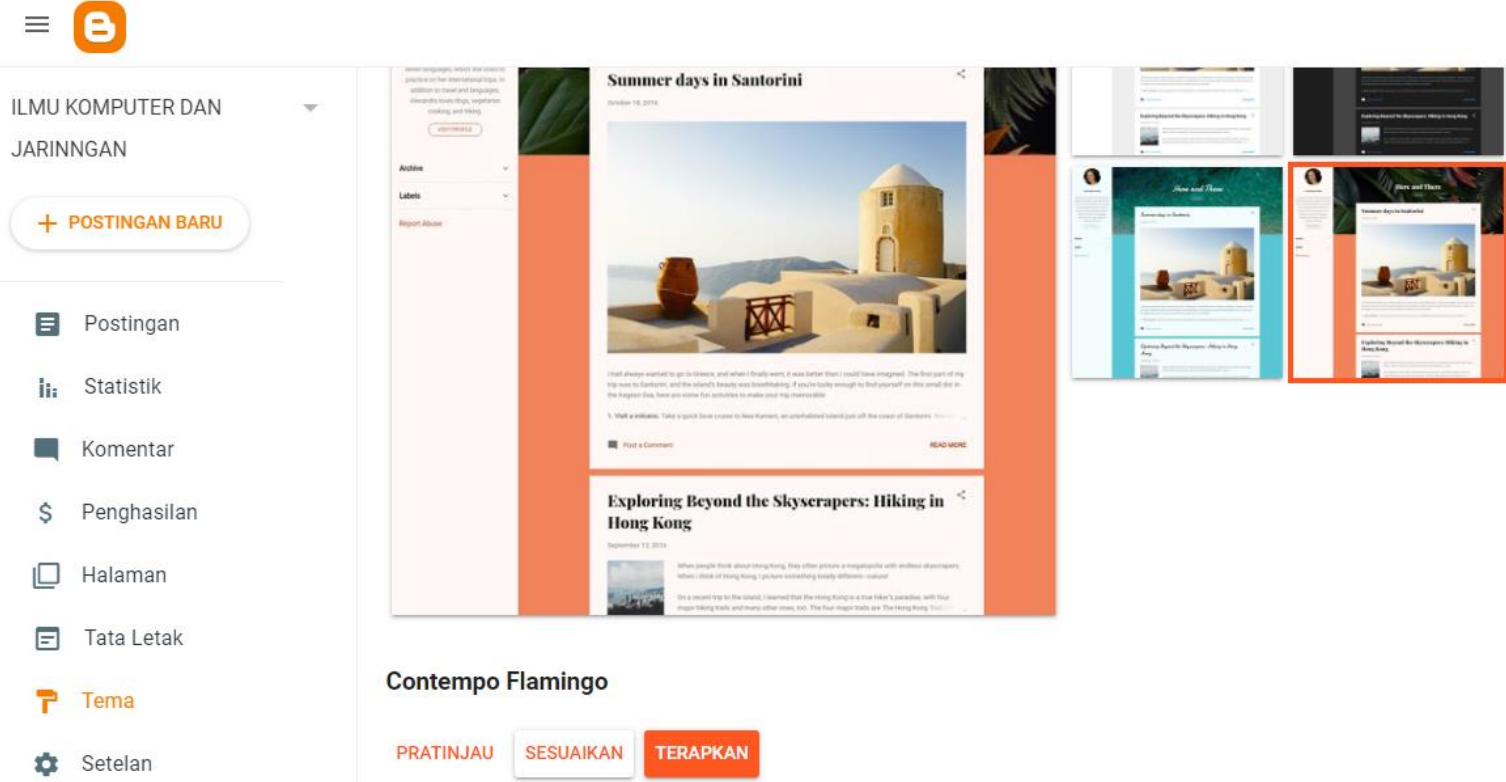

(2)

:::

Contempo Flamingo

PRATINJAU SESUAIKAN TERAPKAN

12. Jika ingin menyesuaikan/custom lebih lanjut tema untuk blog kita, maka klik pada bagian "SESUAIKAN"

$\equiv \Theta$

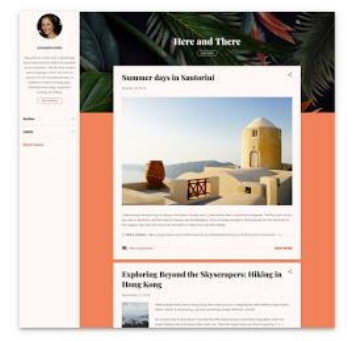

Tema Saya

Contempo Flamingo

SESUAIKAN

\section{ILMU KOMPUTER DAN \\ + POSTINGAN BARU \\ 目 Postingan \\ ii Statistik \\ - Komentar \\ \$ Penghasilan \\ $\square$ Halaman \\ 曰 Tata Letak \\ ? Tema \\ \& Setelan}
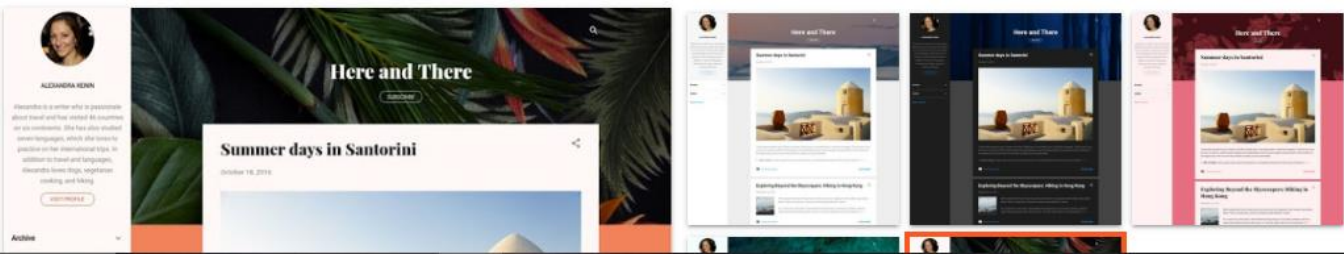
13. Untuk meng-editnya terdapat beberapa pilihan pada bilah sebelah kiri, yaitu : Latar Belakang, Lanjutan(Font, ukuran font, dan warna font), dan gadget. Sedangkan bagian kanan merupakan pratinjau halaman dari apa yang telah kita edit. Untuk save klik pada bagian ujung kanan bawah.
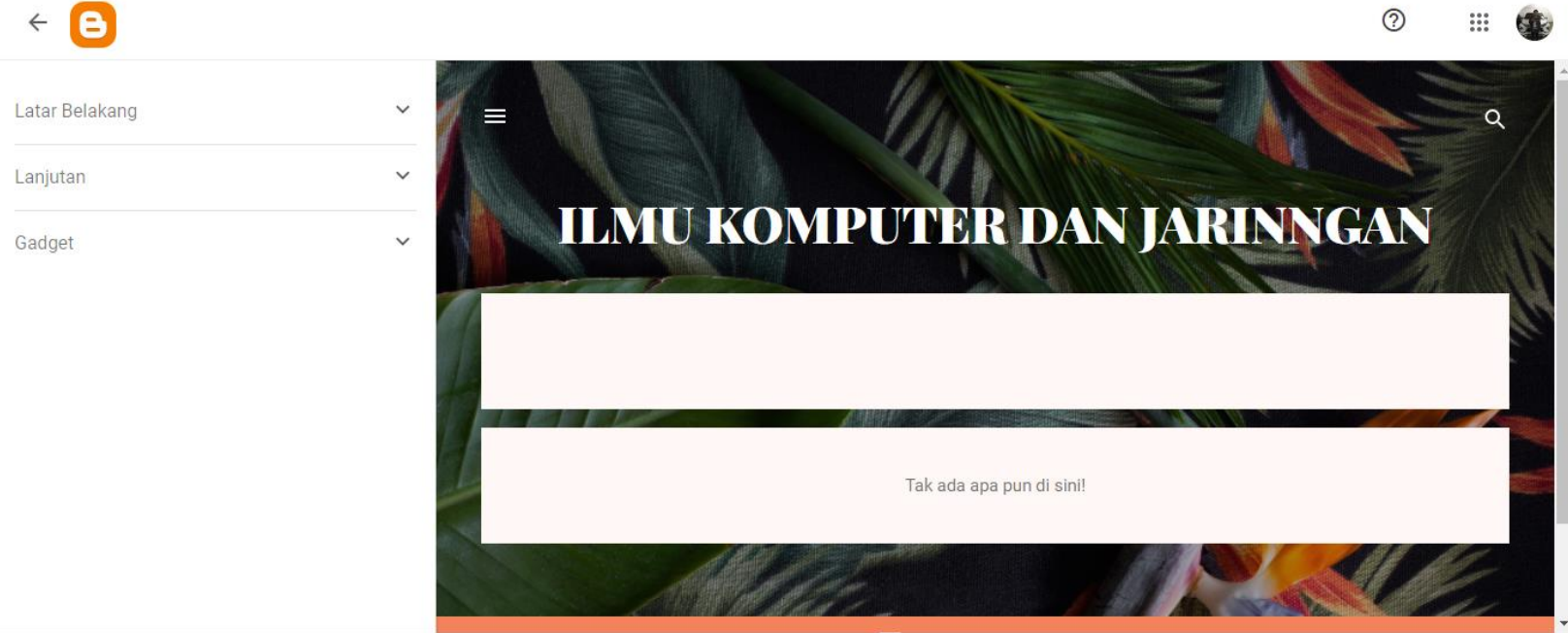

อ

14. Selanjutnya saya akan menjelaskan tentang cara posting di blog, sebelum itu klik kembali pada bagian ujung kiri atas

\section{$\leftarrow \Theta$}

15. Untuk membuat postingan, klik pada bagian "+ POSTINGAN BARU” atau seperti yang saya beri tanda panah di bawah ini.

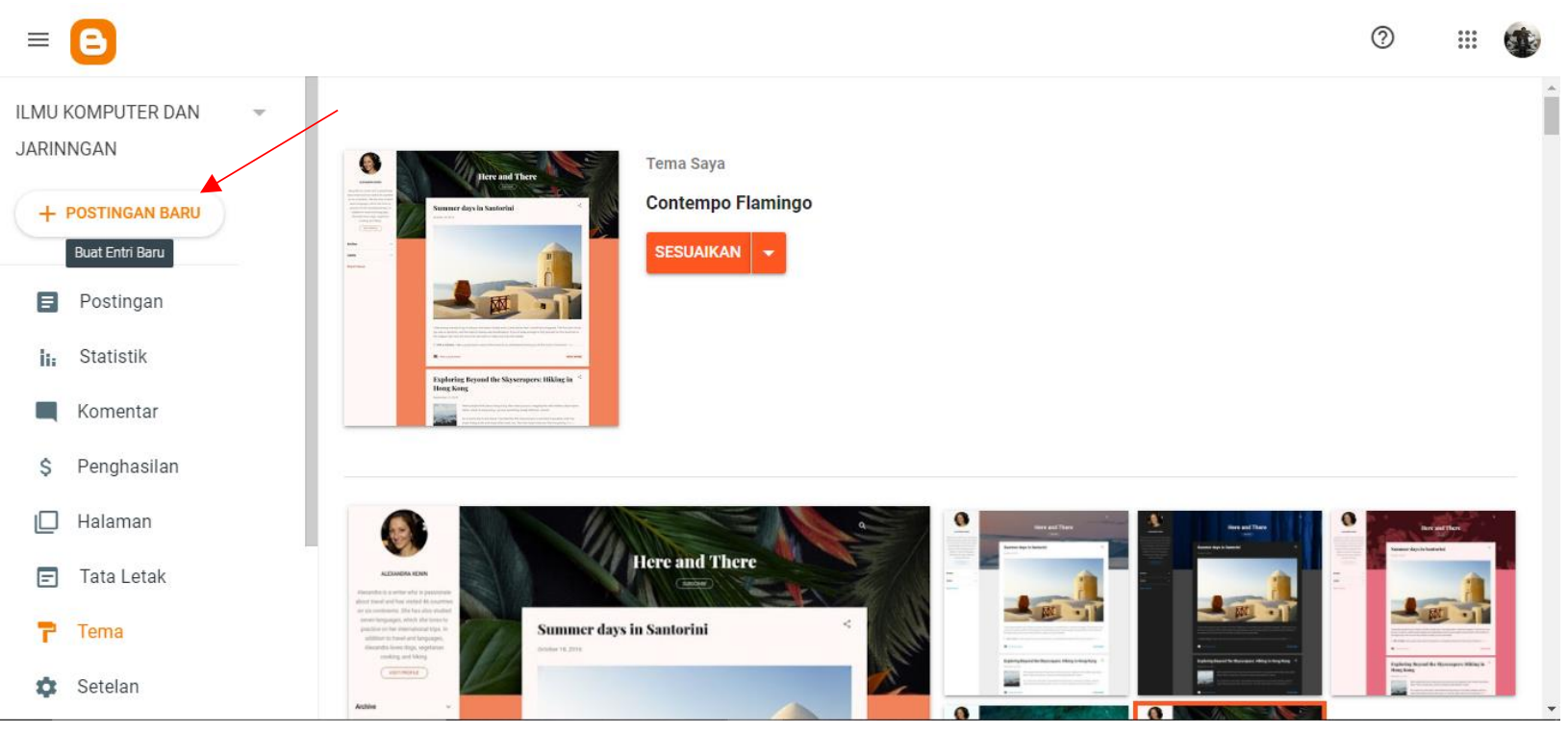


16. Selanjutnya isi judul dan apa yang ingin kita masukkan ke blog kita.

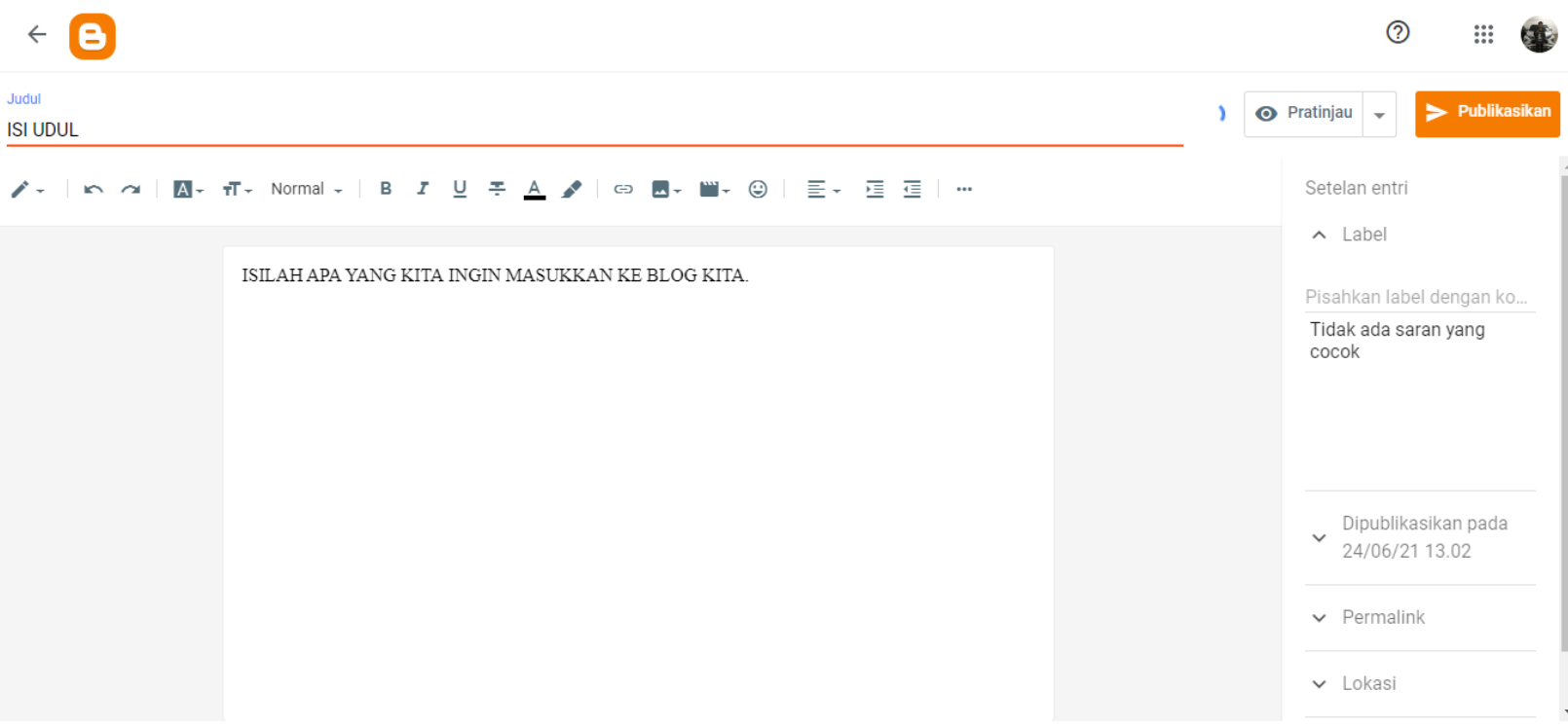

17. Di sini saya ingin posting cara konfigurasi trixbox, jika sudah klik pada bagian "Pratinjau" untuk melihat contohnya dahulu, dan jika sudah pas dengan keinginan kita langsung klik pada bagian "Publikasikan".

KONFIGURASI TRIXBOX

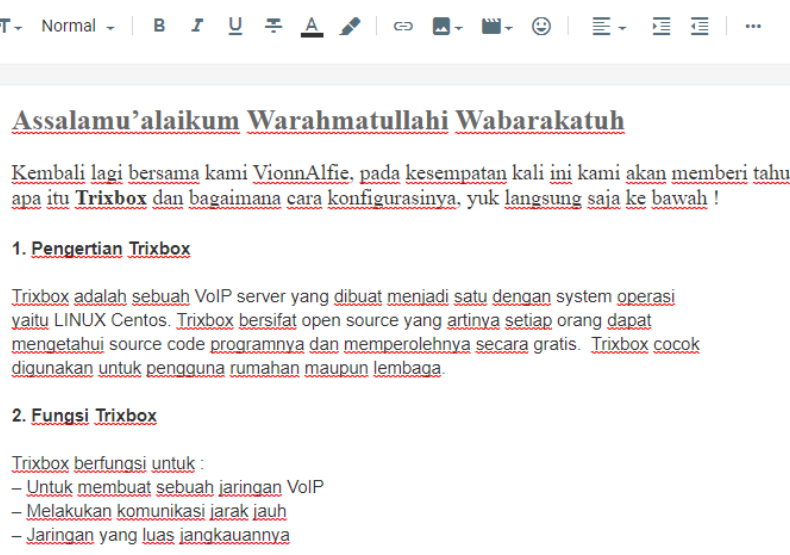


18. Jika sudah diPublikasikan kita akan kembali ke bagian posting, dimana semua postingan yang telah kita publikasikan nanti akan dikumpulkan disini.

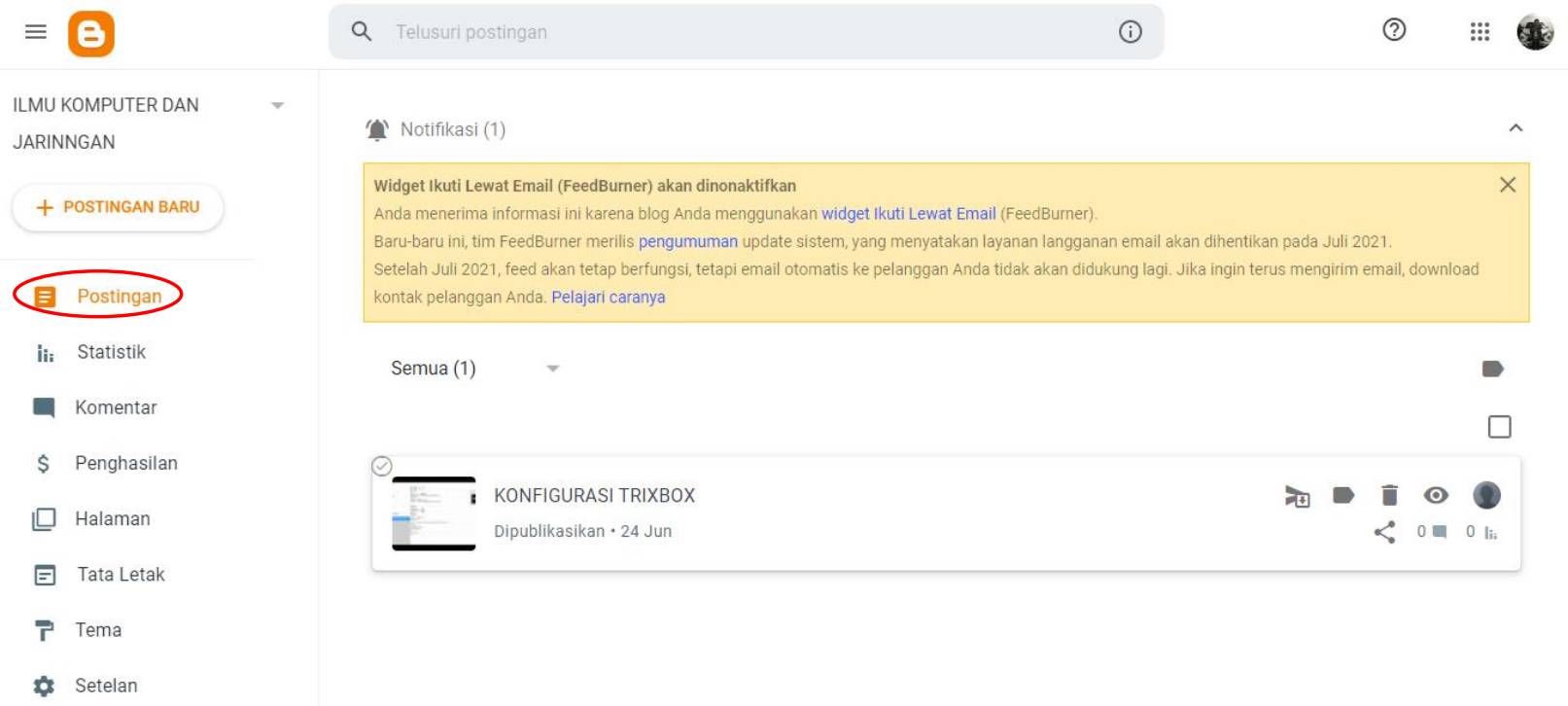

\section{Hasil}

Berikut merupakan hasil dari apa yang telah kita buat sebelumnya :

- Pertama, ini merupakan bagian halaman utama dari blog kita, semua yang kita publikasikan akan ditampilkan di sini. Jika ingin melihat isinya, klik pada judulnya atau yang telah saya beri panah merah di bawah ini.

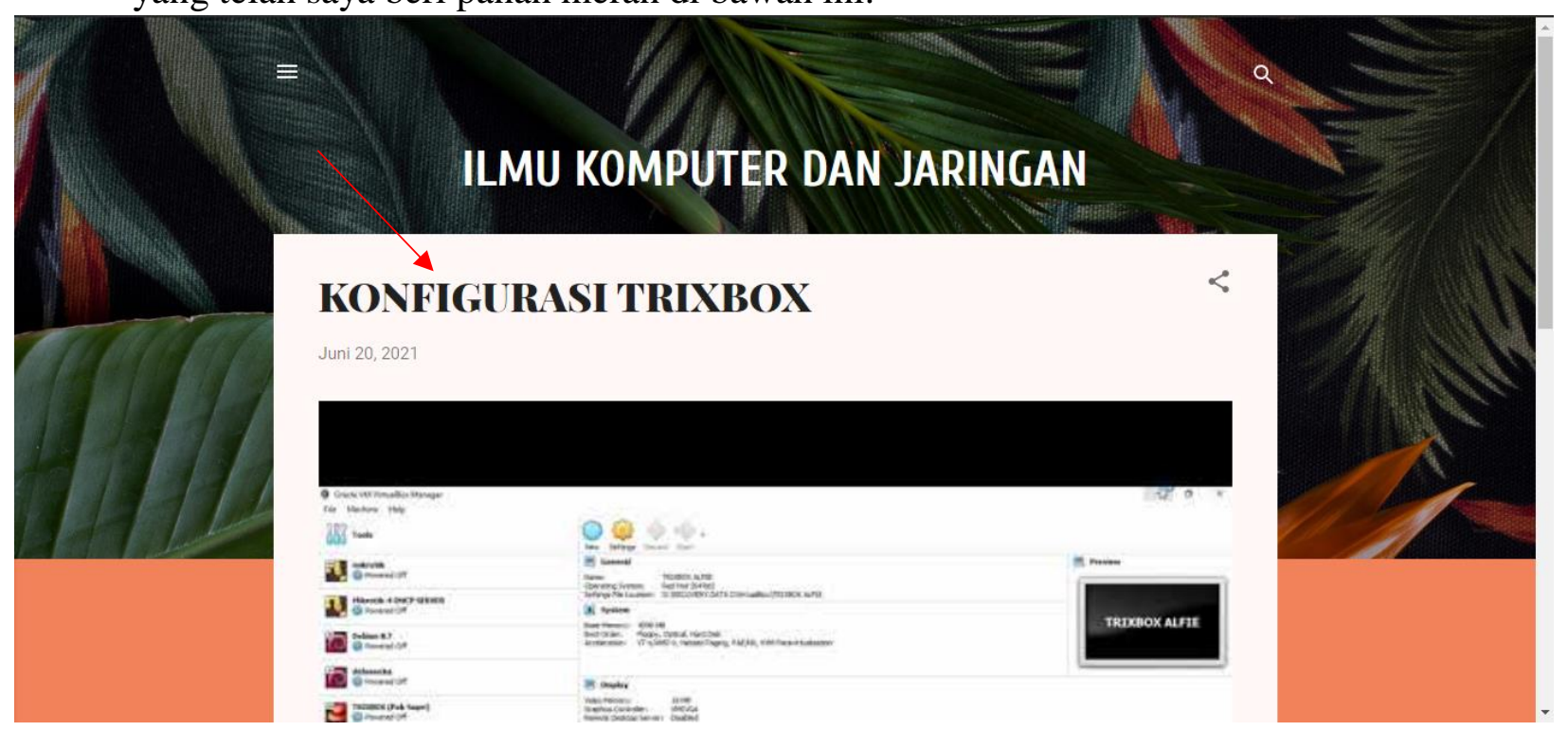


- Maka akan ditampilkan seperti di bawah ini.

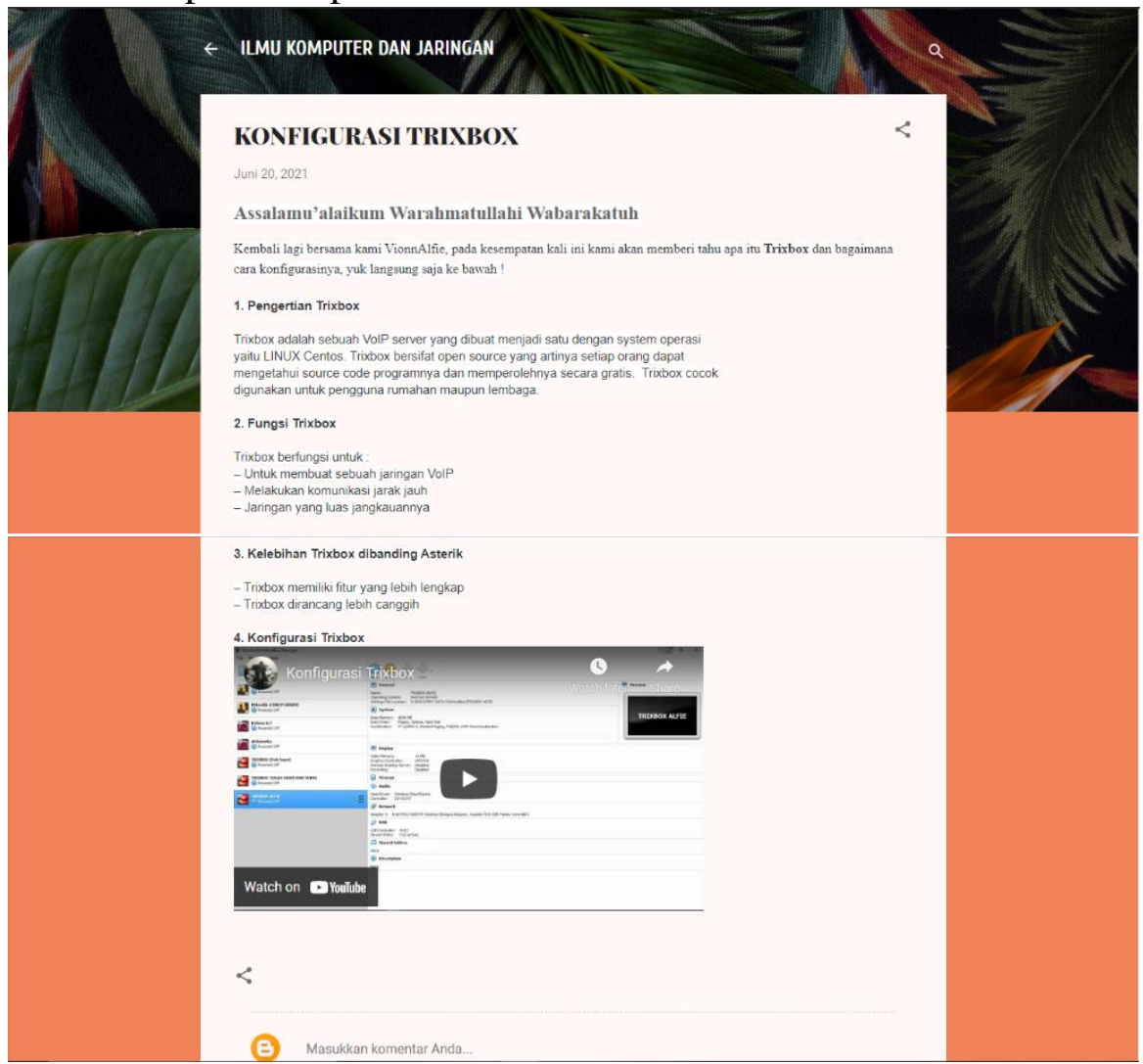

- Jika ingin berkomentar untuk memberikan saran dan kritik, terdapat kolom komentar pada bagian bawah blog.

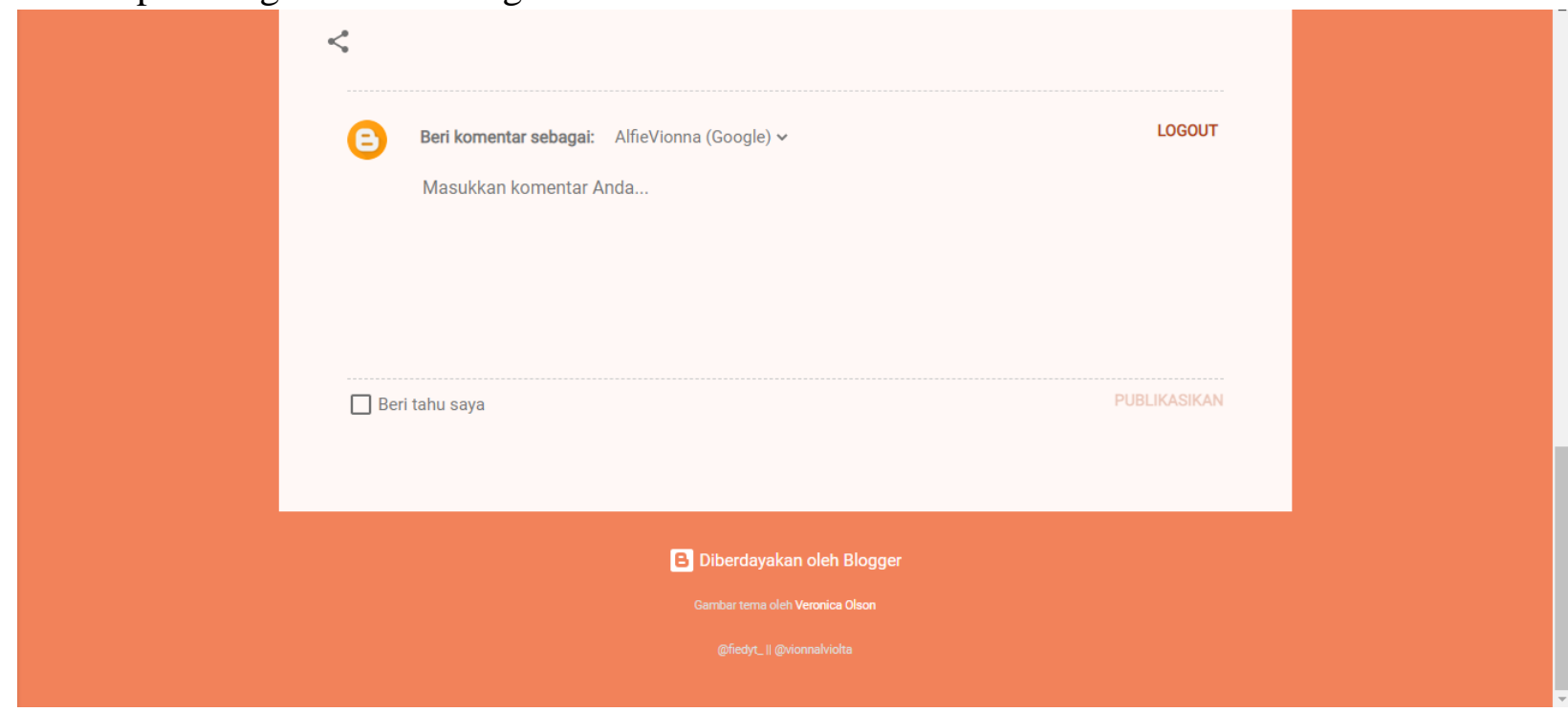




\section{Kesimpulan}

Blog atau Web blog merupakan teks, gambar, objek, media, dan data yang disusun secara hierarkis dan menurut kronologi tertentu dan dapat dilihat melalui internet browser (contohnya chrome). Blog sendiri secara umum mempunyai fungsi utama, yaitu : arsip dan kotak komentar. Terdapat banyak website layanan blog gratis, antara lain : Blogger.com, Blogsome.com, Wordpress.com, Multiply.com, dan Myspace.com. Blogspot.com adalah layanan yang menyediakan blog gratis untuk penggunanya. Meskipun gratis, blog Blogspot.com tidak kalah dengan WordPress self-hosting.

\section{Daftar Pustaka}

[1] F. Metandi, "Perancangan Dan Pembuatan Sistem Informasi Pelaksanaan Praktik Kerja Lapangan (Studi Kasus Jurusan Teknologi Informasi Politeknik Negeri Samarinda)," Just TI (Jurnal Sains Terap. Teknol. Informasi), vol. 11, no. 1, p. 43, 2019, doi: 10.46964/justti.v11i1.130.

[2] "Penjelasan dan Arti Website," [Online]. Available: https://www.indowebsite.co.id/website/.

[3] "Pengertian Blog Beserta Jenis, Fungsi, dan Contohnya," [Online]. Available: https://www.niagahoster.co.id/blog/blog-adalah/.

[4] "MAKALAH TENTANG BLOG," [Online]. Available: http://edikumild.blogspot.com/2016/06/makalah-tentang-blog.html.

[5] "9 Manfaat Blog yang Wajib Anda Ketahui," [Online]. Available: https://www.niagahoster.co.id/blog/manfaat-blog/?amp. 